\title{
O jogo político das expectativas na formulação da Constituição revolucionária mexicana (1910-1917)
}

Edmar Victor Rodrigues Santos ${ }^{1}$

\section{Resumo:}

O objetivo deste artigo será abordar os primeiros anos da Revolução Mexicana, considerando o papel político das expectativas em jogo no processo revolucionário e na leitura que se lhes fez, no momento de formular a nova Constituição, em 1917. Primeiramente, tratarei da leva insurrecional convocada por Francisco Madero e de como, apesar de indicar o início de uma revolução, tentou conduzi-la atado a uma tradição liberal e legalista, que comprometia o seu agir político frente forças estabelecidas do Porfiriato. Passando pela configuração da revolução no norte do país, com destaque para as forças do constitucionalismo, pretendo discutir a própria formulação da Constituição de 1917, através de uma pequena seleção dos debates que lhe deram origem. Esse expediente visa a entrever o papel desempenhado pelos jovens oficiais revolucionários, no sentido de incorporar, no texto constitucional, uma transformação de maior alcance em relação aos Planos de Madero e, seu sucessor, Venustiano Carranza.

Palavras-chave: Revolução Mexicana, expectativas, Constituição de 1917.

\begin{abstract}
:
This article is an analysis of the first years of the Mexican Revolution considering the political role of the expectations about the revolutionary process and its apprehension] in the new Constitutional formulation, in 1917. First, I will focus on the insurrection summoned by Francisco Madero and on how, despite of the evidence of a revolutionary beginning, he have tried to conduct it tied to a liberal and legalist tradition which compromised his political acting in face of the Porfiriato establishment forces. Passing through the revolution configuration on the North of the country, focusing on the constitucionalismo forces, I intend to discuss the Constitution of 1917 formulation analyzing a little selection of the debates that gave birth to it. This procedure aims to see

\footnotetext{
${ }^{1}$ Mestrando em História pelo Programa de Pós-Graduação em História Social (PPGHIS) da Universidade Federal do Rio de Janeiro (UFRJ). E-mail: edmarvictorjr@gmail.com
}

Revista Eletrônica da ANPHLAC, n.12, p. 196-228, jan./jun. 2012. http://revista.anphlac.org.br/index.php/revista 
the young revolutionary officers participation, in the sense of incorporating, in the constitutional text, a larger transformation compared to Madero's and, his successor, Venustiano Carranza's Planes.

Keywords: Mexican Revolution, expectations, 1917's Constitution.

\section{Introdução}

Em 1910, no centenário de sua independência, o México tinha o ar de um país velho, no qual reinava o sentimento de frustração das demandas e expectativas entre os mais diversos estratos da população. As cidades e os centros de produção se massificavam $^{2}$ e, entretanto, o Estado e as empresas não se mostravam preparados (ou dispostos) a garantir o bem-estar do grande fluxo de pessoas que para lá convergiam; pelo contrário. $\mathrm{O}$ exército federal foi frequentemente mobilizado para controlar as agitações da época (KATZ, 2002, p.89-90), no momento em que a expansão dos negócios ia perdendo força. Os confrontos deixavam um grande saldo de violência, como nos casos emblemáticos das greves de Río Blanco ${ }^{3}$ e Cananea ${ }^{4}$.

Esse ano marcava também 34 anos do domínio político de don Porfírio Díaz (período referido como Porfiriato), com o anúncio de que concorreria, mais uma vez, à presidência da República, no pleito agendado para outubro. Contudo, dois anos antes, havia sido publicada a célebre entrevista de Díaz ao jornalista norte-americano James Creelman, sob o sugestivo título de "Héroe de las Américas". Nela, o presidente diz dar "la bienvenida a cualquier partido oposicionista en la República Mexicana", alega não ter desejo de continuar no seu posto após o término do mandato que cumpria e avalia que "esta nación está lista para una vida de libertad definitiva” (DÍAZ, 2010, p.100).

\footnotetext{
${ }^{2}$ Para instigante e erudita análise acerca do processo de massificação das cidades latino-americanas, ver ROMERO, 2004, em especial os capítulos 6 e 7.

${ }^{3}$ Río Blanco era um polo têxtil, em Veracruz, controlado principalmente por capital espanhol e francês, com largo histórico de enfrentamento entre os operários e os patrões e intervenções das forças de segurança pública. Após uma intensa greve no início de 1907, foram convocadas duas companhias do Exército, para além das forças policiais, a fim de controlá-la. (AGUILAR CAMÍN; MEYER, 2000, p.2123)

${ }^{4}$ Cananea era uma cidade mineira na fronteira com o Arizona que, após o investimento de milhões de dólares americanos, explorou cobre vertiginosamente. Os trabalhadores, com a influência do anarcosindicalismo, organizaram-se para reivindicar melhores condições de trabalho. O estabelecimento da greve suscitou violentos confrontos. O impacto dessa série de conflitos foi enorme: após o acontecido, os créditos e mercados de Cananea se fecharam de tal forma que, pouco mais de um ano depois, teve suas atividades encerradas. (AGUILAR CAMÍN; MEYER, 2000, p.20-21)
}

Revista Eletrônica da ANPHLAC, n.12, p. 196-228, jan./jun. 2012. http://revista.anphlac.org.br/index.php/revista 
Essa "bênção" presidencial para a emergência pública de uma nova oposição foi acolhida com entusiasmo e, nesse sentido, organizaram-se clubes, revistas e livros, já tendo em vista as eleições no ano do centenário. Um dos candidatos lançados foi Francisco I. Madero, um abastado fazendeiro do estado de Coahuila, cioso de uma abertura política que, no fim das contas, o regime revelou não estar disposto a conceder. Às vésperas da eleição, ele seria encarcerado; declarada mais uma vitória eleitoral de don Porfírio, Madero e seus apoiadores não enxergaram outra solução possível senão convocar, para o dia 20 de novembro, às $18 \mathrm{~h}$, uma insurreição popular com o fim de depor o presidente pelas armas.

\title{
1- Plano de San Luís Potosí: a "fissura na represa", a insurreição atada ao espaço de experiências e a contestação zapatista.
}

\begin{abstract}
Madero foi uma fissura, inicialmente imperceptível, na eficácia daqueles velhos hábitos [do Porfiriato]. Para sua frágil promessa, acorreram todos os sintomas que a corte porfiriana retardava: fazendeiros com tradição, mas sem futuro, comunidades que resistiam à usurpação de suas terras, profissionais sem cargo, professores revoltados pela miséria e o halo heroico da história da pátria, políticos e militares em conserva. E esta crucial pequena burguesia provinciana: lojistas, farmacêuticos, rancheiros ansiosos, pequenos agricultores e parceiros, todos afogados pelo duplo jugo de suas aspirações locais e da nulidade creditícia e social de suas modestas empresas.

Héctor Aguilar Camín; Lorenzo Meyer. À sombra da Revolução

Mexicana, p.32-33

A insurreição nacional que Francisco Madero convocara, mas para qual não estava preparado, havia se materializado com o óbvio perigo de desencadear movimentos camponeses incontroláveis.
\end{abstract}

John Womack Jr. A Revolução Mexicana, 1910-1920, p.111.

Do exílio no Texas, Madero convocou a insurreição com o Plano de San Luís Potosí, um pequeno texto que desconhecia o governo de Porfírio Díaz e todos os ocupantes de cargos eletivos no país. Sua terceira cláusula resumia uma forte característica do Plano - característica esta que se fez presente também no período o qual Madero foi presidente: trata-se do profundo apego à ordem e às formalidades institucionais que o primeiro caudilho ${ }^{5}$ da Revolução Mexicana possuía ${ }^{6}$. Nesse sentido, chegou a decretar que, para

\footnotetext{
${ }^{5}$ Apesar de estar consciente de que o conceito de "caudilho" muitas vezes foi utilizado como referência pejorativa aos políticos latino-americanos, não é essa minha intenção, uma vez que algumas das fontes com que trabalhei usam o termo em um sentido aparentemente neutro, algo como uma forma particular de designar o "chefe" ou "líder" (essa última muito pouco encontrada nas fontes) de um movimento. As
}

Revista Eletrônica da ANPHLAC, n.12, p. 196-228, jan./jun. 2012. http://revista.anphlac.org.br/index.php/revista 
evitar hasta donde sea posible los trastornos inherentes a todo movimiento revolucionario, se declaran vigentes, a reserva de reformar oportunamente por los medios constitucionales, todas las leyes promulgadas por la actual administración y sus reglamentos respectivos, a excepción de aquellas que manifiestamente se hallen en pugna con los principios proclamados en este Plan. (MADERO, 1979, p.431) [grifo meu]

Há também a menção especial de que "serán respetados los compromisos contraídos por la administración porfirista con gobiernos y corporaciones extranjeras" (Ibidem), claramente destinados aos (muito valiosos) interesses do capital estrangeiro investido no México.

Se tivermos em conta que, em larga medida, as cláusulas do Plano de San Luís Potosí dizem respeito a questões ligadas ao desenvolvimento da insurreição convocada (não reconhecimento das autoridades no poder, formas de estabelecer governos provisórios, financiamento da guerra, etc.), é possível dizer que a maior parte das determinações legais do Porfiriato não entraria em choque com o supracitado Plano, portanto, indicando a sua vigência mesmo após a queda do ditador ${ }^{7}$.

Em princípio, a preservação dos frutos jurídicos do regime anterior parece não ter suscitado grandes problemas para Madero, pois seu chamado à revolução foi razoavelmente atendido, com destaque para a porção norte do país. As diversas guerrilhas revolucionárias que surgiram $^{8}$ conseguiram, depois de alguns combates, forçar a renúncia de Porfírio Díaz; e, se nem todos os bandos reconheciam a autoridade de Madero incontestavelmente - como bem destacou John Womack Jr. (2002, p.110-

Reformas ao Plano de Ayala, por exemplo, referem-se a Emiliano Zapata como "el caudillo del Ejército Libertador Centro-Suriano" (REFORMAS, 1979, p.440).

${ }^{6}$ Nessa linha, um elemento que me pareceu um tanto quanto pitoresco foi que Madero procurou justificar a data marcada para o início do levante da seguinte maneira: "El Gobierno actual [...] puede tener para las naciones extranjeras ciertos títulos de legalidad hasta el 30 del mes entrante [novembro] en que expiran sus poderes; pero como es necesario que el nuevo gobierno imanado del último fraude no pueda recibirse ya del poder o por lo menos se encuentre con la mayor parte de la Nación protestando con las armas en la mano, contra esa usurpación, he designado el Domingo 20 del entrante noviembre para que de las seis de la tarde adelante, en todas las poblaciones de la República se levanten en armas" (MADERO, 1979, p.430). Observa-se aqui o valor que confere ao reconhecimento diplomático pelas nações estrangeiras para a validade de um governo, a despeito de classificá-lo como "tirânico" ao longo do dito Plano. Além do mais, para um leitor desavisado, que se depare apenas com esse fragmento do texto, poderia ficar a impressão de que o "governo imanado da última fraude" não é justamente o mesmo que o "governo atual".

${ }^{7}$ As exceções que considero significativas são: o princípio de não reeleição (declarado Ley Suprema de la República na quarta cláusula); as medidas concernentes a manejos de fundos públicos; e a brevíssima menção ao problema da terra - sobre a qual falarei melhor adiante.

${ }^{8}$ De acordo com Womack (2002, p.111), havia em torno de 25 mil revolucionários mobilizados nesse momento.

Revista Eletrônica da ANPHLAC, n.12, p. 196-228, jan./jun. 2012. http://revista.anphlac.org.br/index.php/revista 
111) -, também não há relatos de algum que tenha, no início, desafiado a sua liderança de maneira mais direta. Não tardou, entretanto, para seu apoio político começar a desmoronar.

Após cerca de seis meses de começados os combates, a paz foi selada com Díaz através dos Tratados de Ciudad Juárez (1911) que, no seu curtíssimo texto, não faz qualquer alusão ao Plano de San Luís Potosí - em teoria, o documento que embasava a causa da revolução - ou mesmo qualquer determinação política e social; limitou-se a formalizar a renúncia de Díaz e de seu vice-presidente, repassar o governo provisório ao Secretário de Relações Exteriores - conforme a ordem constitucional - e a promessa de que o novo governo "estudiará las condiciones de la opinión pública en la actualidad para satisfacerlas en cada estado dentro del orden constitucional" (TRATADOS DE CIUDAD JUÁREZ, 2010, p.222). Segundo comentário de James Wilkie e Albert Michaels (1969, p.40), o próprio Madero teria reconhecido que sacrificou suas promessas anteriores, justificando um compromisso com o antigo regime, a fim de não prolongar o estado de guerra civil instalado.

Não obstante o acordo conseguido, que pavimentou sua vitória em novas eleições convocadas para aquele mesmo ano, foi ele também a fonte da instabilidade endêmica que o caudilho teve que enfrentar no pouco tempo em que conseguiu manterse na presidência (1911-1913, pouco menos de 17 meses). Como já foi dito, os Tratados em questão ignoraram completamente o Plano de San Luís Potosí e, mantendo como presidente provisório um dos velhos secretários e a maior parte dos funcionários públicos, selavam uma aliança com a administração que o próprio Madero havia descrito com todo o repúdio anos antes ${ }^{9}$. Ademais, foi tomada a impopular decisão, em consonância ao respeito de Madero à "normalidade institucional", de reconhecer a autoridade do Exército federal - maior sustentáculo do Porfiriato - e partir então para o

\footnotetext{
9 Atacando um dos mais fortes argumentos de propaganda do Porfiriato, a "paz prolongada" proporcionada após um século XIX marcado por guerras, Madero irá dizer que essa era "una paz vergonzosa $[\ldots]$ porque no tiene por objeto el engrandecimiento y prosperidad de la Patria, sino enriquecer un pequeño grupo que, abusando de su influencia, ha convertido los puestos públicos en fuente de beneficios exclusivamente personales, explotando sin escrúpulos las concesiones y contratos lucrativos" [grifo meu] (MADERO, 1979, p.428).
}

Revista Eletrônica da ANPHLAC, n.12, p. 196-228, jan./jun. 2012. http://revista.anphlac.org.br/index.php/revista 
licenciamento das forças revolucionárias armadas: as mesmas que tinham tornado possível a queda dos 34 anos de domínio político de don Porfírio ${ }^{10}$.

O que Madero parecia não haver entendido, entretanto, era que a insurreição convocada por ele não foi bem um movimento único e coeso, mas sim - na expressão utilizada por Héctor Aguilar Camín e Lorenzo Meyer - a "fissura na represa" do Porfiriato (2000, p.32). Provocou-se uma grande alteração das circunstâncias políticas, com um tremendo afluxo de pessoas dispostas a protestar - de armas na mão - por suas próprias expectativas refreadas até aquele momento. O panorama de então dificilmente permitiria um retorno à ordem tal como era: os "horizontes de expectativas" dos revolucionários começava a obliterar o "espaço de experiências" tradicional da política mexicana ${ }^{11}$. Ignorando (ou lutando contra) esse cenário, o presidente se posicionava “confinado pela velha legalidade" e quis, através dela,

aplacar a agitação e as expectativas que tinham sido despertadas no país que pretendia governar, para estabelecer um novo governo e não uma nova ordem na República que experimentava espasmos convulsivos. [grifos meus] (Idem, p. 38)

A insatisfação de seus apoiadores iniciais, diante dessa postura, logo se fez sentir. Ainda durante o governo provisório, surgiu uma dissidência importante, liderada pelo candidato à vice-presidência na chapa maderista derrotada em 1910 - Francisco Vázquez Gómez -, insatisfeito com o compromisso travado com a velha ordem e o abandono do Plano de San Luís Potosí (Idem, p. 39). Já empossado como presidente, Madero enfrentou também a rebelião conduzida por Pascual Orozco, um dos principais combatentes desde os primeiros levantes, sendo inclusive o chefe responsável pela

${ }^{10}$ Talvez inspirado na catástrofe política dessa decisão de Madero, o armistício estabelecido na fase seguinte da revolução, pelos Tratados de Teoloyucan, determinava a pronta dissolução do Exército federal, de maneira que o governo se sustentaria militarmente pelas tropas de extração revolucionária. Cf. TRATADOS DE TEOLOYUCAN, 2010.

${ }^{11}$ Espaço de experiências é uma categoria fundamental utilizada por Reinhart Koselleck na sua análise dos discursos e dos conceitos políticos, permitindo-lhe perceber como, em determinado contexto, os homens se orientam no tempo. Para defini-la, resumidamente, o autor nos diz: "tem sentido dizer que a experiência proveniente do passado é espacial, porque ela se aglomera para formar um todo em que muitos estratos de tempos anteriores estão simultaneamente presentes, sem que haja referência a um antes e um depois." (KOSELLECK, 2006, p.311). Sua contraparte é o horizonte de expectativas que, juntamente com a categoria anterior, auxiliam a quem delas se apropria no objetivo de compreender e, em certa medida equacionar, sob que termos a experimentação temporal de um determinado contexto se desenvolve. Sobre o horizonte de expectativas, Koselleck diz: "horizonte quer dizer aquela linha por trás da qual se abre no futuro um novo espaço de experiência, mas [...] a possibilidade de se descobrir o futuro [...] se depura com um limite absoluto, pois ela não pode ser experimentada" (Ibidem). Para uma explanação mais apurada, ver KOSELLECK, 2006, p.305-327.

Revista Eletrônica da ANPHLAC, n.12, p. 196-228, jan./jun. 2012. http://revista.anphlac.org.br/index.php/revista 
tomada de Ciudad Juárez: a cidade mais importante da fronteira norte, onde ficou instalado o governo provisório durante a guerra e iniciaram-se as negociações para pôr fim às hostilidades contra Díaz (WOMACK, 2002, p.111).

Outro fator crucial para a insatisfação de diversos revolucionários com o novo presidente diz respeito ao seu aparente pouco-caso quanto ao problema agrário do país. Retornando à terceira cláusula do plano maderista, consta ali a importante (e breve) menção dos abusos das expropriações de terra ocorridas durante o Porfiriato. Reconhecendo a justiça da causa dos pequenos proprietários em recuperarem suas terras, Madero estabeleceu que todas as ações ocorridas no sentido de desapropriá-los estariam sujeitas à revisão. Essa promessa, ainda que limitada, contemplava um enorme contingente da população mexicana, predominantemente camponesa, convocando-o a lutar pela causa da revolução, sob a liderança maderista.

Contudo, uma promessa de "revisão" não era bem uma promessa de "terra"! E essa "atitude acadêmica do governo" (Idem, p.116), somada à omissão da questão nos Tratados de Ciudad Juárez, irá lhe custar o apoio de muitos daqueles que lutaram em nome do Plano de San Luís Potosí no início e que consideravam como suas, por direito tradicional (em alguns casos remontando ao século XVIII), vastas porções de terras detidas então por grandes fazendeiros. Um de seus defensores iniciais, que se sentiu traído tão logo o novo governo tomou posse, foi Emiliano Zapata, cujo programa lançado na villa Ayala constituiu uma das mais contundentes denúncias da política de Madero e que veio a se tornar, com seu Exército Libertador do Sul, a mais persistente força política armada no México até o fim da guerra civil.

O manifesto zapatista retomava o Plano de San Luís Potosí, mas, nas adições que lhe fez, levou as reivindicações revolucionárias a outro patamar, muito distantes da postura do caudilho anterior. A primeira diferença substancial reside na forma de encarar o antigo regime, essencialmente preservado por Madero, em nome do rápido retorno à estabilidade: o Plano de Ayala expressava um repúdio sem reservas por aquele, não admitindo

ni transacciones ni componendas políticas hasta no conseguir el derrocamiento de los elementos dictatoriales de Porfírio Díaz y don Francisco I. Madero, pues la Nación está cansada de hombres falaces y traidores que hacen promesas como libertadores pero que, al llegar al poder, se olvidan de ellas y se constituyen en tiranos. [grifo meu] (PLAN DE AYALA, 1979, p.437)

Revista Eletrônica da ANPHLAC, n.12, p. 196-228, jan./jun. 2012. http://revista.anphlac.org.br/index.php/revista 
Na sequência, passava a falar do problema agrário, que não só mereceu maior destaque em comparação ao programa maderista, como expressava uma radical mudança na forma de encarar a questão. Está posto em sua sexta cláusula:

\begin{abstract}
Como parte adicional del plan que invocamos [Plan de San Luis Potosí], hacemos constar: que los terrenos, montes y aguas que hayan usurpado los hacendados, científicos o caciques a la sombra de la justicia venal, entrarán en posesión de esos bienes inmuebles desde luego, los pueblos o ciudadanos que tengan sus títulos, correspondientes a esas propiedades, de las cuales han sido despojados por mala fe de nuestros opresores, manteniendo a todo trance, con las armas en las manos, la mencionada posesión, y los usurpadores que se consideren con derechos a ellos, lo deducirán ante los tribunales especiales que se establezcan al triunfo de la Revolución. [grifos meus] (Ibidem)
\end{abstract}

Conforme é possível observar, a "atitude acadêmica" diante da questão é substituída pela restituição imediata das terras expropriadas aos pueblos $^{12}$ e cidadãos reclamantes, reservando-lhes o direito de defender suas propriedades de armas na mão! Também aqui fica invertida a lógica anterior, pois, agora, quem deveria protestar junto aos tribunais seriam aqueles reconhecidos como usurpadores e que, antes da revolução, gozavam das ditas terras. Indo além, o referido Plano dispõe, após constatar a precária condição da maioria dos mexicanos, que os "grandes monopólios" (de terras e indústrias) seriam completamente expropriados para que fossem redistribuídos ao povo nas mais diversas formas - com o único escrúpulo de se pagar uma indenização no valor não maior do que a terceira parte do total (sétima cláusula) $)^{13}$.

A deposição, seguida pela execução, de Francisco Madero pelo gal. Victoriano Huerta, em fevereiro de 1913, não alterou as resoluções dispostas no programa zapatista original, limitando-se a transferir sua condenação para o novo governo golpista. $\mathrm{O}$ Exército Libertador do Sul seguiria forte, ampliando cada vez mais seu controle sobre a região centro-sul do país, e o Plano de Ayala, se não era o único dos "Planos" que respaldavam a luta armada que se estendia ao longo do território nacional, era, sem dúvida, o mais radical em termos sociais. É possível dizer ainda que era esse o Plano que mais longe levava o horizonte de expectativas dos revolucionários, ampliando o seu

\footnotetext{
${ }^{12}$ Uma das tradições existentes no México, quanto ao uso da terra, refere-se ao compartilhamento de certa porção de terra (ou de mananciais, montes etc.) por certo grupo de pessoas em uma aldeia, de forma que pueblo pode aludir tanto ao grupo de pessoas quanto à porção de terra comum por eles utilizada.

${ }^{13}$ No caso daqueles que interpunham uma oposição direta ao Plano de Ayala, estava disposto que teriam todos os seus bens nacionalizados, destinando dois terços do valor para indenizações de guerra e fundos de pensão para viúvas e órfãos de guerra (PLAN DE AYALA, 1979, p.437).
}

Revista Eletrônica da ANPHLAC, n.12, p. 196-228, jan./jun. 2012. http://revista.anphlac.org.br/index.php/revista 
distanciamento frente à experiência prévia e às reivindicações mais tímidas de maior liberdade política. Se tomarmos o exemplo de Venustiano Carranza (a quem voltarei em seguida), vemos um maderista fiel que abriu uma nova frente de batalha após o golpe de Huerta, mas ignorou qualquer causa social ou econômica na redação original do seu Plano de Guadalupe (1913). O outro principal líder de raízes populares do momento, Francisco "Pancho" Villa, só iria proclamar sua própria lei agrária em meados de $1915^{14}$. Nesse momento, já estava formada a Soberana Convenção Revolucionária ${ }^{15}$, da qual se tornou comandante militar e onde os zapatistas tinham grande preeminência, sendo os mais importantes formuladores legais ${ }^{16}$.

Diante da vitória iminente dos exércitos revolucionários sobre Huerta, em meados de 1914, Zapata emitiu a Ratificação do Plano de Ayala, pretendendo reforçar os princípios pelo qual lutava, enfatizando que

\begin{abstract}
la Revolución debe proclamar altamente que sus propósitos son en favor, no de un pequeño grupo de políticos ansiosos de poder, SINO EN BENEFICIO DE LA GRAN MASA DE LOS OPRIMIDOS Y QUE, POR TANTO, SE OPONE Y SE OPONDRA SIEMPRE A LA INFAME PRETENSION DE REDUCIRLO TODO A UN SIMPLE CAMBIO EN EL PERSONAL DE LOS GOBERNANTES, del que ninguna ventaja sólida, ninguna mejoría positiva, ningún aumento de bienestar ha resultado ni resultará nunca a la inmensa multitud de los que sufren. [grifos do original] (RATIFICACIÓN, 1979, p.442)
\end{abstract}

Com essa Ratificação, creio que fica ainda mais nuançada a diferença entre Francisco Madero e o movimento zapatista, tendo em conta os seus princípios - ou talvez mesmo suas expectativas - diante do movimento revolucionário, naquilo em que sejam passíveis de apreender dos textos seus Planos. Ambos, por exemplo, invocaram, em diferentes momentos, a Constituição de 1857 e a figura do herói liberal oitocentista, Benito Juárez. Todavia, a deferência de Madero para com o arcabouço institucional e

\footnotetext{
${ }^{14}$ Essa aparição tardia da lei agrária de Pancho Villa certamente não exclui a possibilidade de que esse tenha empreendido restituições de terras ou iniciativas semelhantes. De todo modo, creio que tal fato indica um menor interesse sistemático da facção villista diante do problema agrário.

${ }^{15}$ A Soberana Convenção Revolucionária foi formada, no fim de 1914, com o intuito de promover discussões acerca do futuro do país, após a derrocada do governo de Victoriano Huerta; para isso, convocou todos aqueles envolvidos na luta contra o general golpista. Era composta por diversos grupos heterogêneos e, para preencher o vazio de poder deixado pela renúncia de Huerta e, ao mesmo tempo, buscar um nome que transitasse entre os diversos grupos, foi nomeado como presidente interino o general revolucionário Eulálio Gutiérrez. Carranza, que sempre se reconheceu como líder máximo e inconteste da Revolução, achou esse ato inadmissível e se retirou da Convenção (BARBOSA, 2008, p. 9-11).

${ }^{16}$ A Ley Agraria de la Soberana Convención Revolucionaria foi decretada em outubro de 1915, poucos meses depois da proclamada por Villa, e subscrita por cinco ministros do governo convencionista: todos eles zapatistas.
}

Revista Eletrônica da ANPHLAC, n.12, p. 196-228, jan./jun. 2012. http://revista.anphlac.org.br/index.php/revista 
jurídico já deixado por essa tradição - somada à sua preservação dos principais elementos do Porfiriato - era largamente oposta à disposição de Zapata para o imediato atendimento às demandas e necessidades por terras, a serem defendidas pelo próprio povo em armas. No caso dos ideais zapatistas, a alteração constitucional - prevista na Ratificação - seria a consagração desses princípios de aplicação imediata, enquanto, para Madero, o expediente formal seria, na melhor das hipóteses, o ponto de partida para que se fizesse algo além do que lhes obrigava a ordem estabelecida.

Entretanto, quando esse texto zapatista foi elaborado, não mais existia Francisco Madero como principal adversário político - executado sob os cuidados de Victoriano Huerta. Esse último, por sua vez, também já abandonara a presidência, após cerca de um ano de guerra civil. O momento era de negociação entre os diversos caudilhos revolucionários, quando despontava, no norte, o exército constitucionalista, ${ }^{17}$ sob a liderança de Venustiano Carranza. Na sequência, pretendo abordar panoramicamente a configuração das forças político-militares nortistas, com ênfase na jovem oficialidade ali atuante, enfatizando a sua grande importância para que os princípios de transformação mais radical fossem levados à frente - posteriormente desaguando na Constituição de 1917.

\title{
2 - Os "jovens oficiais" do constitucionalismo: revolução para além do Plano de
}

\section{Guadalupe}

\begin{abstract}
Mientras esto se sucedía, se habló mucho y largo, entre la juventud que rodeaba al gobernador coahuilense, de formular un plan revolucionario en que se proclamaran como razones de la lucha los principios sociales, que más tarde debían de ser la invencible bandera de la Revolución. [...] Pensaba [Carranza], con la entereza de hombre cuerdo, que la ley ultrajada era el argumento menos discutible para justificar la lucha sangrienta iniciada por él e iba, así, emplazando nuestra fogosidad y nuestra impaciencia sin negarnos la razón en la amplitud de nuestro ideal. En esta constante pugna ideológica del sostenedor de la ley y de las aspiraciones juveniles que no era otra cosa que las necesidades del pueblo, la lucha continuaba siempre adversa y cada día más dificil. [grifo meu] (MÚGICA apud SILVA HERZOG, 1972a, p.23)

Francisco J. Múgica apud Jesús Silva Herzog. Breve Historia de la Revolución Mexicana. La etapa constitucionalista y la lucha de
\end{abstract} facciones, p.23.

\footnotetext{
${ }^{17}$ A alcunha de "constitucionalista", forjada por Carranza, era com respeito à Constituição de 1857, que ele enxergava como violada por Porfírio Díaz e depois por Victoriano Huerta. Também é possível entender a escolha do nome como uma ressonância do princípio legalista que também animou Carranza, no início.
} 
O relato acima remete, anos depois, ao início de 1913, quando o governador constitucional de Coahuila, Venustiano Carranza, reuniu, na fazenda de Guadalupe, um grupo de oficiais formados pela luta maderista e que primeiro lhe apoiou em seu repúdio ao golpe do gal. Victoriano Huerta. Os presentes dedicavam-se a discutir a formulação de um "plano" que orientasse a luta armada, a ser liderada pelo então governador, sob o título de "Primeiro Chefe". O autor do referido relato foi Francisco J. Múgica, na época um jovem oficial de 29 anos de idade. Ao mencioná-lo em primeira instância, pretendo ressaltar um caso-limite de um destacado revolucionário nortista, que proclamava a necessidade de aproveitar a oportunidade da guerra para proporcionar uma transformação mais profunda da realidade mexicana. Com a contundência de poucos, Múgica expressou sua ambição em dar vazão a uma enorme carga de expectativas até então sufocadas, projetando um horizonte de ação revolucionária mais além do que a simples "sustentação da legalidade". Com esse relato inicial, pretendi marcar a discrepância entre o "Primeiro Chefe" e boa parte dos líderes militares que lhe secundavam, ainda que a clareza e radicalidade de Múgica não possam bem ser generalizadas a todos aqueles oficiais.

Ainda sobre Múgica, vale mencionar que ele foi um dos principais encarregados pelo primeiro ato proeminente desempenhado por essa jovem oficialidade. $\mathrm{O}$ dito ato ficou registrado como a primeira repartição de terras ocorrida no norte do país, em agosto de 1913, apenas alguns meses depois da assinatura do Plano de Guadalupe. A sua liderança coube ao gal. Lucio Blanco, que comandava as forças constitucionalistas nos estados de Nuevo León e Tamaulipas. Segundo o testemunho de Juan Barragán Rodríguez, outro jovem oficial que atuava naquelas fileiras, o referido general era o mais popular caudilho militar nesses momentos iniciais da revolução constitucionalista (BARRAGÁN RODRÍGUEZ, 1985, p.128). O episódio começou com a tomada, por Blanco, da importante cidade de Matamoros, situada na fronteira com os EUA, contrariando prognósticos de outros líderes militares ${ }^{18}$. Com a cidade conquistada, o general empreendeu a expropriação da fazenda vizinha, chamada Los Borregos, de proporções medianas, mas com significado político enorme: esse terreno era de propriedade de Félix Díaz (ULLOA, 1981, p.1121), o sobrinho de don Porfírio que três

${ }^{18}$ Para relato acerca dos preparativos e da tomada de Matamoros, cf. BARRAGÁN RODRÍGUEZ, 1985, p.122.

Revista Eletrônica da ANPHLAC, n.12, p. 196-228, jan./jun. 2012. http://revista.anphlac.org.br/index.php/revista 
vezes organizou um golpe militar contra Francisco Madero. Para a repartição de terras, foi marcada uma cerimônia solene, com programação diversificada, na qual o próprio general responsável entregaria aos camponeses que ali trabalhavam títulos de propriedade dos pequenos lotes demarcados ${ }^{19}$.

$\mathrm{Na}$ dita cerimônia, o momento proeminente teria ficado por conta do então major Francisco Múgica, chefe do Estado Maior das tropas de Blanco e impulsionador do ato, proferindo um discurso (infelizmente não encontrado), no qual, de acordo com Barragán,

condenó el régimen feudal de la propiedad, lanzando sus anatemas contra la servidumbre y el despotismo de las oligarquías criollas, y manifestando que en un país como México, eminentemente agrícola, los destinos del pueblo y de la Patria están vinculados al cultivo de la tierra. (BARRAGÁN RODRÍGUEZ, 1985, p.174-175)

Como bem lembrou Jesús Silva Herzog, "esta distribución se hizo sin ningún apoyo legal; se hizo revolucionariamente, a la brava, como se dice en la jerga popular" (SILVA HERZOG, 1972a, p.37). Sua importância aumenta, se ainda considerarmos que, à exceção do movimento zapatista no Sul, não havia nenhum "plano" revolucionário que lhe encorajasse ou definisse os termos sob os quais poderia ocorrer. Ou seja, não havia nada que lhe conferisse um caráter "formalmente" legítimo. Essa ação tão simbólica, orquestrada por Múgica e Blanco, desafiava a ordem legal e, igualmente, a submissão plena à Primeira Chefatura, indo muito além do que o Plano de Guadalupe lhes teria autorizado. Carranza, que se arrogava o último repositório da legalidade no país após o golpe huertista, parecia ter se desagradado com tal feito, tendo ordenado, pouco depois, que Blanco entregasse o comando de suas tropas, convocandoo a Hermosillo, capital do governo constitucionalista, para receber novas atribuições ${ }^{20}$.

19 O programa da cerimônia celebrada pela repartição de Los Borregos consta em BARRAGÁN RODRÍGUEZ, 1985, p.174-176. O que me pareceu mais intrigante sobre o conteúdo desse documento é perceber que o primeiro dos atos solenes realizados foi a entoação da Marselhesa.

${ }^{20}$ Cf. SILVA HERZOG, 1972a, p.37. Juan Barragán Rodríguez apresenta uma justificativa diferente para esse fato. Segundo ele, o que se passou foi que, no início da luta constitucionalista, Lucio Blanco respondia diretamente ao Primeiro Chefe, pela proximidade geográfica entre a sede do gabinete desse e a área de atuação militar daquele. Quando Carranza transferiu-se para Sonora, Blanco teria fícado supostamente sob a autoridade do gal. Pablo González, o mais alto comandante militar da área. Todavia, Blanco não estava de acordo em se submeter à autoridade de um general, que havia perdido o controle da zona que lhe cabia anteriormente, e submeter a sua própria, a qual conquistou sem outras forças que não sua coluna original. Na sequência, Carranza despachou uma comissão de militares designada para fazer valer as ordens da Primeira Chefatura. Para relato mais detalhado desses eventos, ver BARRAGÁN RODRÍGUEZ, 1985, p.251-256.

Revista Eletrônica da ANPHLAC, n.12, p. 196-228, jan./jun. 2012. http://revista.anphlac.org.br/index.php/revista 
Esse ato revolucionário, feito a la brava, não foi o único protagonizado por esses militares nortistas que, submetidos ao Plano de Guadalupe e a Carranza, não se deixaram restringir completamente por isso. Dos que foram encontrados registro explícito, destaca-se o período entre agosto e setembro de 1914, quando uma série de estados foi conquistada pelos constitucionalistas, no que se seguiram decretos feitos pelos comandantes militares de cada local, visando, por exemplo, a acabar com a escravidão por dívidas dos trabalhadores do campo e garantir-lhes direitos básicos, tais como jornada máxima de trabalho e salário mínimo (Idem, p.147-148). Nesse conjunto, merece menção especial, pela sua abrangência, o decreto expedido pelo gal. Eulálio Gutiérrez, no estado de San Luís Potosí, antes ainda desse se tornar o presidente provisório da Soberana Convenção Revolucionária. Ademais de estabelecer uma jornada máxima e salário mínimo, ficou estipulada uma série de disposições no sentido de extinguir a escravidão de facto a qual estavam submetidos os camponeses. A fim de realçar a diferença com a precária situação anterior ao decreto, destaco, dentre seus vários tópicos, a concessão do direito de mudar de emprego e de residência livremente; de comerciar com quem quisessem; além de terem todas as suas dívidas perdoadas (GUTIÉRREZ, 1972).

Nessa conjuntura, não creio ser precitado dizer que esses revolucionários nortistas se tornaram forças capazes de "acelerar seu próprio futuro"; como os zapatistas do sul (guardadas as suas não poucas diferenças), eles tinham a transformação constitucional no seu horizonte, mas não esperaram por ela para promover uma luta revolucionária, que fosse mais do que um combate militar e que visasse apenas à reclamação da legalidade prévia. Como expressou Múgica sobre aquela assembleia reunida para a formulação do Plano de Guadalupe, não se tratava de falar ao povo apenas "de la razón legal de la guerra, sino de la oportunidad, de la necesidad vindicar las usurpaciones desde la tierra hasta la del poder, desde la económica hasta la política" [grifo meu] (MÚGICA apud SILVA HERZOG, 1972a, p.28).

Da parte de Carranza, seria imprudente dizer que ele ignorava por completo a causa da transformação social, apesar de, na conjuntura revolucionária, manter sua orientação política atada à fórmula tradicional já expressada por Madero. Jesús Silva Herzog recorda do discurso pronunciado pelo Primeiro Chefe, ainda em 1913, no qual

Revista Eletrônica da ANPHLAC, n.12, p. 196-228, jan./jun. 2012. http://revista.anphlac.org.br/index.php/revista 
pontua a necessidade e a justiça da luta social e tenta justificar seu programa revolucionário ao dizer:

el Plan de Guadalupe no encierra ninguna utopía, ninguna cosa irrealizable, ni promesas bastardas hechas con la intención de no cumplirlas. El Plan de Guadalupe es un llamado patriótico a todas las clases sociales, sin ofertas y sin demandas al mejor postor. (CARRANZA, 1972b, p.62)

A postura desse discurso, que também se mostra no relato acima sobre a assembleia originária do Plano (apud SILVA HERZOG, 1972a, p.28), era a de ater-se à causa legalista como bandeira unificadora das forças revolucionárias. Pretendia assim (ao não enunciar "utopias" ou "promessas bastardas"), que a guerra fosse vencida o mais breve possível para depois, enfim, realizar o fim maior da revolução que, nas suas palavras, "es establecer la justicia, es buscar la igualdad, es la desaparición de los poderosos, para establecer el equilibrio de la conciencia nacional" (CARRANZA, 1972b, p.62). Todos esses grandiosos objetivos teriam, nessa lógica, que esperar a nova Constituição que se elaboraria para começar a ser atingidos.

O mais curioso sobre essa atitude de Carranza (promover uma guerra rápida para só depois atacar os problemas nacionais mais profundos), que em muito lembra Francisco Madero, é perceber a drástica mudança ocorrida em menos de dois anos. Em dezembro de 1914, logo em seguida ao rompimento com a Convenção e sua fuga para o porto de Veracruz, o Primeiro Chefe lança as Adições ao Plano de Guadalupe, nas quais reafirma a subsistência do plano original, mas modifica - em termos formais - a margem de atuação programática do exército constitucionalista. O novo principal inimigo eleito foi o gal. Francisco Villa que, além de suas negativas em insubordinar-se a Carranza, estaria sendo apoiado pelos mesmos elementos "reacionários" que teriam impedido Madero de orientar sua política em sentido radical e concorrido para a queda $\operatorname{desse}^{21}$. Os agentes villistas, no entendimento carrancista, teriam impossibilitado que a Convenção pudesse realizar os propósitos para o qual foi convocada (CARRANZA, 1972a, p.199) e, por isso,

el Primer Jefe de la Revolución constitucionalista tiene la obligación de procurar que, cuanto antes, se pongan en vigor todas las leyes en que deben

21 Jesús Silva Herzog faz constar um relato que escreveu quando foi correspondente jornalístico na Convenção, afirmando que Villa "por su odio al señor Carranza, aceptó en múltiples ocasiones los servicios de personas de filiación reaccionaria” (1979a, p.167). Entre eles, estavam antigos políticos e latifundiários, como José María Maytorena, ex-governador de Sonora e desafeto de importantes generais constitucionalistas, como, por exemplo, Álvaro Obregón (AGUILAR CAMÍN; MEYER, 2000, p.37).

Revista Eletrônica da ANPHLAC, n.12, p. 196-228, jan./jun. 2012. http://revista.anphlac.org.br/index.php/revista 
cristalizarlas reformas políticas y económicas que el país necesita expidiendo dichas leyes durante la nueva lucha que va a desarrollarse. [grifos meus] (Ibidem)

Ou seja, a partir desse momento, a transformação social não mais esperava a vitória política definitiva e sim tornava-se um elemento fundamental para que essa vitória ocorresse. Como expediente pragmático, o decreto autorizava a "hacer las expropiaciones por causa de utilidad pública que sean necesarias para el reparto de tierras, fundación de pueblos y demás servicios públicos", assim como "hacer, directamente, o por medio de los jefes que autorice, las requisiciones de tierras, edificios, armas, caballos, vehículos, provisiones y demás elementos de guerra" [grifo meu] (Idem, p.201-202). Na direção dessa reconhecida necessidade de se expedir leis e agir revolucionariamente, antes que a guerra chegasse ao seu fim, vieram a lei agrária carrancista em janeiro de 1915 e a "autorização" da Primeira Chefatura para que o gal. Álvaro Obregón lançasse um decreto sobre o salário mínimo que incidisse sobre os estados controlados por seu exército.

É arriscado precisar a razão para o chefe constitucionalista ter considerado, no fim de 1914, que as transformações sociais eram uma necessidade imediata, diferentemente do que expressou no início de 1913, quando da primeira versão do Plano de Guadalupe. Se o motivo legalista perdeu força após a queda de Huerta, criando uma conjuntura na qual toda a legitimidade política remanescente foi adquirida durante e em nome da revolução, Carranza jamais abandonou a convicção de que a liderança exercida sobre o seu movimento emanava de seu antigo cargo de governador constitucional do estado de Coahuila, de forma que só fazia acatar o decreto da legislatura estadual, para tomar as armas e reparar a violação huertista ${ }^{22}$.

Uma hipótese possível para compreender a nova postura é a mudança do adversário. Contra Huerta, não havia qualquer dúvida, entre os revolucionários, de que o inimigo representava a tentativa de retornar ao antigo regime (Porfiriato), tendo como sustentação alguns banqueiros, alguns grandes empresários, a alta hierarquia do clero e,

${ }^{22}$ Esse princípio fica claramente reafirmado pelas Adiciones del Plan de Guadalupe (CARRANZA, 1972a, p.194-195)

Revista Eletrônica da ANPHLAC, n.12, p. 196-228, jan./jun. 2012. http://revista.anphlac.org.br/index.php/revista 
principalmente, o Exército federal ${ }^{23}$ (SILVA HERZOG, 1972a, p.40; WOMACK, 2002, p.126). Já em 1914, ainda que a Divisão do Norte de Francisco Villa tenha acolhido muitos elementos conservadores, sendo esse o principal argumento de Carranza para reiniciar a guerra, havia ali conteúdo - e força armada - direcionado para as causas sociais que animavam os demais revolucionários; Eulálio Gutiérrez, autor do mais importante decreto pelos direitos trabalhistas até o momento, era o presidente da Convenção, que tinha Villa como seu comandante militar; some-se a isso o movimento zapatista, que por mais que não tenha ultrapassado expressivamente sua concentração nos estados do Sul, sua presença na Convenção foi decisiva ideologicamente (SILVA HERZOG, 1972a, p.159) e, poucos dias antes das “Adições”, Zapata e Villa firmaram uma aliança estratégica em encontro na cidade de Xochimilco, no qual o mais acalorado ponto da conversa foi seu ódio mútuo pelo Primeiro Chefe ${ }^{24}$.

Outra possibilidade de interpretar a mudança na forma de Carranza encarar o movimento revolucionário diz respeito aos líderes militares que lhe acompanhavam, dos quais cada vez mais dependia militar e politicamente - destacando-se, entre eles, Álvaro Obregón. Como foi indicado, a oficialidade constitucionalista já vinha tomando iniciativas, no sentido de alterar a realidade social de suas áreas de controle militar, bem antes que o Primeiro Chefe resolvesse dar a essas ações um caráter formal.

Em suma, o(s) inimigo(s) dos constitucionalistas (longe de se resumir apenas a Francisco Villa) vinha(m) realizando ações que visavam a uma transformação maior das condições socioeconômicas da população. E os jovens líderes militares do exército constitucionalista, com anuência ou não de Carranza ${ }^{25}$, também. Dessa forma, é possível inferir que, para poder contar com o apoio popular e dos seus próprios militares, pouco restava ao Primeiro Chefe fazer, senão buscar recolocar-se na liderança de um movimento que já estava tomando seu próprio curso, tentando conservar sua autoridade

\footnotetext{
${ }^{23}$ O efetivo do Exército federal passou de 60 mil homens, no último ano do governo Madero, para a impressionante cifra de 250 mil homens nos últimos meses de Huerta no poder (WOMACK, 2002, p.117; p.130).

${ }_{24}$ "Eles [Zapata e Villa] irromperam em uma torrente verbosa o seu ódio mútuo pelo Primeiro Chefe, e seu diálogo foi animado por mais de uma hora. 'Carranza,' disse Villa, 'é um homem muito - bem, muito insolente...'. Zapata concordou: "Eu sempre disse que... que Carranza é um canalha [scoundrel]"” (QUIRK, 1969b, p.80). [tradução minha]

${ }_{25}$ Além da repartição de Blanco, o decreto de Eulálio Gutierrez não leva assinatura ou autorização explícita de Carranza, o que era o expediente normal para o reconhecimento de uma determinação do exército constitucionalista, tal como demonstra o decreto de Obregón sobre o salário mínimo (OBREGÓN, 1979, p.261).
} 
e consolidar suas alianças, na hora em que a guerra civil entrava em seu ponto mais crítico e devastador, com combates massivos entre as tropas inimigas ${ }^{26}$.

Essa hipótese parece se confirmar quando confrontada com os trabalhos do Congresso Constituinte de Querétaro, convocado no final de 1916, quando os constitucionalistas conseguiram assentar sua hegemonia político-militar sobre o país. Apesar da condição de que apenas poderiam integrar o Congresso quem nunca tivesse sido hostil à causa constitucionalista (CARRANZA, 1959, p.312), ou seja, quem sempre reconheceu a autoridade máxima de Carranza, o grupo que apoiou as suas propostas de reforma constitucional era claramente minoritário, de maneira que o protagonismo ficou por conta dos jovens oficiais que haviam garantido a vitória nos campos de batalha. $\mathrm{O}$ gal. Álvaro Obregón, por exemplo, laureado com os triunfos militares sobre Villa, foi o ponto de referência maior entre os deputados mais claramente esquerdistas (ROUAIX, 1959, p.63), fazendo-se presente nos bastidores de Querétaro, para dar apoio às propostas radicais feitas nos debates. Francisco Múgica, por sua vez, seria o presidente da primeira Comissão de Constituição (Idem, p.197), encarregada de apresentar os ditames a serem discutidos pelos deputados constituintes. Se esse grupo não chegava a negar abertamente a autoridade do Primeiro Chefe, retomava, implícita ou explicitamente, suas críticas à timidez das propostas daquele para transformação do país que tanto ansiavam.

\title{
3 - Congresso Constituinte de Querétaro: jacobinos versus renovadores ou "as conquistas do passado não são mais suficientes"
}

\begin{abstract}
Hubo izquierdas exaltadas que ambicionaban radicalismos violentos y hubo derechas moderadas que se alarmaban ante el peligro de drásticas medidas; [...] siendo de notar para honra del Congreso y satisfacción de sus electores, que en todos los casos de acaloradas discusiones, le dio el triunfo a los radicales, demostrando con ello, su ardiente revolucionarismo.

Los diputados que figuraron en los puestos prominentes de las izquierdas fueron los revolucionarios que habían luchado con las armas en la mano en los campos de batalla y los jóvenes de sangre ardiente que por no tener arraigo en el pasado, deseaban destruirlo rápidamente para entrar de lleno al porvenir del idealismo que habían soñado; [...] algunos de los cuales no alcanzaban la edad legal de los 25 años.

El ala derecha tuvo como núcleo fundamental a los ex diputados renovadores que habían laborado en la Secretaría de Instrucción Pública, tantas veces citados: [...] pequeño grupo al que había quedado reducido el bloque maderista de la XXVI Legislatura después de las deserciones y escisiones
\end{abstract}

26 Aguilar Camín e Meyer traçam um rico retrato acerca desse momento, com destaque para o ano de 1915, quando "exércitos revolucionários ocupam todo o campo visual” (2000, p.73).

Revista Eletrônica da ANPHLAC, n.12, p. 196-228, jan./jun. 2012. http://revista.anphlac.org.br/index.php/revista 
que lo desmenuzaron. En el Congreso Constituyente este reducido número de personas apareció como un escudo o baluarte que detuvo y resistió todos los ataques que los revolucionarios necesitaban lanzar contra el gran conjunto primitivo. [...] Se completaba el grupo con algunos amigos personales del señor Carranza, hombres respetables por su edad a quienes se aplicó el mote de "el apostolado".

Pastor Rouaix. Génesis de los artículos 27 y 123 de la Constitución política de 1917, p.62-64

O longo trecho acima é da autoria do deputado constituinte Pastor Rouaix e foi mantido nessa extensão porque, para os objetivos pretendidos neste artigo, acredito ser o melhor resumo encontrado a respeito da composição do Congresso Constituinte, reunido entre dezembro de 1916 e janeiro de 1917, na cidade de Querétaro ${ }^{27}$.

O objetivo inicial dos deputados eleitos seria reformar a antiga Constituição liberal de 1857, a partir de um projeto enviado por Venustiano Carranza, que se apresentava como Encarregado do Poder Executivo. Os historiadores consultados que falaram sobre o assunto foram unânimes em acentuar a insatisfação da maior parte dos constituintes a respeito do dito projeto: Jesús Silva Herzog falou da sua demasiada "timidez" ou "prudência" (SILVA HERZOG, 1972a, p.305); Lyle C. Brown diz que ainda na Comissão de Constituição - encarregada de apresentar os ditames a serem debatidos - ele foi considerado muito "limitado, particularmente quanto a problemas socioeconômicos como educação pública [art. $3^{\circ}$ ], distribuição de terra [art. 27], garantias trabalhistas [art. 123], e regulação das organizações religiosas [art. 130]" (BROWN, 1969, p.113) [tradução minha]; por fim, Héctor Aguilar Camín e Lorenzo Meyer, de maneira mais contundente, destacaram que era apenas "o projeto que se poderia esperar de um governante como Carranza, formado no horizonte liberal do século XIX, que a ditadura porfiriana havia burlado na realidade, sem eliminá-lo das leis" (AGUILAR CAMÍN; MEYER, 2000, p.85). Ainda de acordo esses dois autores, o Primeiro Chefe estaria "surdo e cego, por formação e idade, às poderosas demandas sociais do conflito do qual acabava de sair vitorioso [...]" (Ibidem).

Como foi indicado na epígrafe dessa seção, o projeto carrancista teve no grupo dos renovadores - ou "ala direita" - os seus principais advogados. O dito grupo remontava aos deputados maderistas da famigerada XXVI legislatura. Esses

\footnotetext{
${ }^{27}$ Rouaix também elenca um terceiro grupo, mais difuso, que teria dado equilíbrio às duas tendências principais, destacando a si mesmo como integrante, uma vez que era um colaborador próximo de Carranza (ocupava o posto de Secretário do Fomento), mas também atuou como um crítico de suas propostas - principalmente quanto ao artigo 27 (ROUAIX, 1959, p.64).
}

Revista Eletrônica da ANPHLAC, n.12, p. 196-228, jan./jun. 2012. http://revista.anphlac.org.br/index.php/revista 
contemplaram chocados a quartelada de Victoriano Huerta e permaneceram no Congresso depois do golpe, até a sua dissolução definitiva em outubro de 1913 (HUERTA, 1972). O fato de terem continuado como congressistas após o golpe foi fruto de muitas contestações, pois teriam assim contribuído para a pretensa imagem de legitimidade daquele governo (ROUAIX, 1959, p.62).

O encargo de levar os artigos constitucionais supracitados além do "horizonte liberal do século XIX", ficou por conta do desempenho do outro grupo de deputados que, por seu radicalismo, foi chamado - dentre outros nomes - de ala jacobina ${ }^{28}$. Essa ala da Constituinte "queria reconhecer também as pegadas ainda frescas das demandas sociais subjacentes à Guerra Civil (afinal, ainda havia 50 mil homens armados espalhados pela República)" (AGUILAR CAMÍN; MEYER, 2000, p.86). Para demonstrar essa visão, escolhi duas intervenções de dois eminentes jacobinos: gal. Heriberto Jara, deputado pelo estado de Veracruz, falando sobre o artigo 27; e, sobre o artigo $3^{\circ}$, Francisco Múgica - deputado por Michoacán ${ }^{29}$.

Primeiramente, falarei do artigo 27, o qual me parece ser o mais importante da nova Constituição, por tentar resolver tanto o problema da grande concentração de terras existente, quanto o da soberania nacional sobre seu solo e riquezas do subsolo. $\mathrm{O}$ historiador Adolfo Gilly resumiu os termos do artigo da seguinte maneira:

\begin{abstract}
Este artículo otorga a la nación la propiedad originaria sobre el territorio, a partir de la cual se constituye la propiedad privada como un derecho que la nación puede ceder a los particulares; establece el principio de la restitución o la dotación de ejidos a los pueblos, y declara que los productos del subsuelo (minas y petróleo) son propiedad inalienable de la nación, no de los particulares que pueden detentar la propiedad del suelo.
\end{abstract}

\footnotetext{
${ }^{28}$ Também se referiu a esse grupo de deputados como obregonistas, dado o papel aglutinador desses constituintes desempenhado pelo gal. Álvaro Obregón nos bastidores do Congresso (ROUAIX, 1959, p.63). Outro epíteto ao qual atenderam foi de ala esquerda. O curioso, quase anedótico, é que os mais radicais militares sentavam-se do lado direito do salão onde foram realizadas as seções (ROJAS, 1967, p.88).

${ }_{29}^{29}$ Vale anotar que Jara também participou da primeira repartição de terras do norte feita por Lucio Blanco, ainda que nada indique ter ele desempenhado o mesmo destaque de Francisco Múgica. A trajetória pessoal desses dois generais-deputados é mesmo similar em alguns pontos importantes: jovens oficiais nortistas que sobressaíram politicamente nos trabalhos da Constituinte; depois ambos ficaram um pouco fora dos holofotes políticos nacionais, durante a década de 1920, por suas diferenças com os presidentes sonorenses da época; e ambos retornaram ao centro do poder nos anos 1930, ao serem chamados pelo presidente radical Lázaro Cárdenas, para desempenhar funções cruciais para o governo. Jara foi nomeado Inspetor Geral do Exército, responsável por disciplinar os generais de oposição, e assumiu a chefia do partido do governo no delicado momento da sucessão presidencial; Múgica, por sua vez, foi ministro de governo até o ano final do mandato de Cárdenas e chegou a ser forte candidato na corrida sucessória, por ser considerado como o que maior afinidade ideológica tinha com o programa cardenista.
} 
Esta disposición se remitía, como antecedente, a las Ordenanzas de Aranjuez, dictadas en 1793 por el rey Carlos III [...].

El artículo 27 estableció así esta propiedad originaria como uno de los elementos integrantes de la soberanía de la nación. En la estructura del precepto esa propiedad originaria se manifestaba en dos derechos: el derecho de los campesinos mexicanos a la tenencia o la posesión del suelo y el derecho del Estado mexicano a la propiedad sobre los productos del subsuelo. En esta arquitectura jurídico-conceptual, el suelo y el subsuelo son propiedad de la nación. [grifos meus] (GILLY, 2001, p.141)

O texto final foi aprovado de forma unânime; Silva Herzog (1972a, p.318) atribuiu a singularidade dessa votação ao intenso trabalho realizado fora das seções do Congresso pelo deputado Pastor Rouaix, membro da Comissão de Constituição, contando com grande ajuda de vários constituintes e do advogado Andrés Molina Enríquez: esse não era deputado, mas foi autor do livro Los grandes problemas nacionales, "primera exposición fundada y concreta de la desorganización nacional proveniente de la desastrosa distribución de la tierra en el país" (ROUAIX, 1959, p.147) ${ }^{30}$. Rouaix também exercia o cargo de Secretário de Fomento, mas, apesar de ser um dos principais elos entre o Congresso e o governo provisório de Carranza, não hesitou em criticar a primeira proposta desse para a questão da propriedade territorial, argumentando que

\begin{abstract}
las modificaciones que proponía el Sr. Carranza eran importantes para contener abusos y garantizar el cumplimiento de las leyes en otros conceptos del derecho de propiedad; pero no atacaba el problema fundamental de la distribución de la propiedad territorial que, debia estar basado en los derechos de la nación sobre ella y la conveniencia pública. Por este motivo, el debate del artículo 27 se había estado posponiendo indefinidamente, porque, al comprender su deficiencia, se esperaba que pudiera ser presentado con toda la amplitud indispensable para dar satisfacción completa al problema social más vasto y más trascendental, que tenía enfrente la Revolución, [...]. [grifo meu] (ROUAIX, 1959, p.146-147)
\end{abstract}

Segundo Eduardo Miranda Correa, o postulado do primeiro parágrafo ${ }^{31}$ desse artigo

era notable por la capacidad teórica y política que tenía para agarrar y hacer confluir no sólo los intereses encontrados entre las diversas fuerzas sociales y militares y tendencias políticas que se encontraban representadas en el Congreso de Querétaro, sino también porque tomaba como problemas sociales las demandas primordiales de las fuerzas derrotadas, zapatistas y

\footnotetext{
${ }^{30}$ Molina Enríquez também foi o redator do plano da insurreição antimaderista liderada por Francisco Vázquez Gómez (AGUILAR CAMÍN; MEYER, 2000, p.39), mencionado na seção 2 deste artigo.

31 "La propiedad de las tierras y aguas comprendidas dentro de los límites del territorio nacional corresponde originariamente a la nación la cual ha tenido y tiene el derecho de transmitir el dominio de ellas a los particulares, constituyendo la propiedad privada" (MÉXICO, 2010, p.886).
}

Revista Eletrônica da ANPHLAC, n.12, p. 196-228, jan./jun. 2012. http://revista.anphlac.org.br/index.php/revista 
villistas, como problemas que afectaban directamente los intereses generales de la "nación". (MIRANDA CORREA, s/d, p.785)

A forma adotada, creditada a Molina Enríquez, modificava substancialmente a concepção liberal de propriedade privada, uma vez que essa não se constituiria mais por si mesma e sim sob a autorização da "nação". Ou seja, "los derechos generales de la sociedad estuvieron antes y por encima de los derechos generales de los propietarios privados" (Idem, p.786).

Detenho-me agora no deputado Heriberto Jara. É possível dizer que ele viveu, com especial intensidade, a questão da soberania nacional sobre a propriedade agrária e as riquezas do subsolo. Digo isso, porque desempenhou a maior parte de sua atuação militar no estado de Veracruz, o qual viveu, desde o início do século, um enorme boom petrolífero, estimulado no governo Díaz ${ }^{32}$. Dentre outras facilidades, o Porfiriato aprovou uma legislação que permitia ao dono de um determinado terreno explorar as porventura existentes riquezas do subsolo sem qualquer tributação adicional e a propriedade mineira, devidamente reconhecida, era irrevogável e perpétua ${ }^{33}$. Como o deputado aludiu em sua fala, a situação das regiões petrolíferas era então muito delicada, já que a esmagadora maioria dos terrenos estava em mãos de empresas estrangeiras, que se sentiam no direito, "cuando no se hace su soberana voluntad, hasta de impetrar fuerza extraña para hacer respetar sus derechos de propiedad, adquiridos por una cantidad verdaderamente irrisoria" [grifo meu] (JARA, 1967, p.220). A "fuerza extraña" mencionada parece ser em referência à ocupação do porto de Veracruz, pelos marines norte-americanos, durante os meses de abril e novembro de $1914^{34}$.

Com esse argumento, adicionado ao reconhecimento de que o grito de "terra" foi o principal motivador das tropas revolucionárias (Idem, p.223), Jara pedia aos seus colegas constituintes a aprovação do artigo 27, tal como apresentou a Comissão de Constituição; e ele assim o pede, mesmo que o texto não caiba em um critério, no que me deu a entender, de estrita jurisprudência. Nesse ponto, seu discurso é bastante elucidativo sobre como a Constituição de 1917 veio a compor o que Reinhart Koselleck

\footnotetext{
${ }^{32}$ A produção de petróleo "de 3,3 milhões de barris em 1910 subiu para 14 milhões em 1911, um salto enorme que subitamente colocou o país em terceiro lugar entre os países produtores de petróleo do mundo" (AGUILAR CAMÍN; MEYER, 2000, p.29).

${ }^{33}$ Cf. MÉXICO (país), 1892.

${ }^{34}$ Para breve análise sobre a ocupação norte-americana do porto de Veracruz, ver. AGUILAR CAMÍN; MEYER, 2000, p.65-66.
} 
chamou de "campo de expectativa social"35. Isso nada mais seria do que a incorporação do conteúdo do horizonte de expectativas de um dado momento revolucionário em um símbolo que lhe dava força normativa, compelindo a concretizar os ideais então esboçados a todos aqueles que pretendessem estar ao lado da revolução. Creio que é possível inscrever nessa linha, uma interessante interrogação do jacobino mexicano:

Pero insisto sobre lo que cabe o lo que debe caber y no debe caber en la Constitución. [...] ¿Quién ha hecho la pauta de las Constituciones? ¿Quién ha señalado cuantos centímetros que debe tener una Constitución, quien ha dicho con cuántos renglones, con cuántos capitulos, y con cuántas letras son las que deben formar una Constitución? Es ridículo sencillamente; eso ha quedado reservado al criterio de los pueblos, eso ha obedecido a las necesidades de los mismos pueblos; la formación de las Constituciones no ha sido otra cosa sino el resultado de la experiencia, el resultado de los deseos, el resultado de los anhelos del pueblo, condensados en eso que se ha dado en llamar Constitución. [...] Estas reformas que al principio parecieron ridículas, eso que al principio se consideró como que no cabía, va a ser recibido en las naciones del nuevo continente con beneplácito. [grifos meus] (Idem, p. 221222)

As palavras de Heriberto Jara ainda registrariam seu profundo anticlericalismo (Idem, p.222; p.225) - bastante próprio dos jacobinos mexicanos - e, no fim, traça uma retoricamente arrebatadora comparação com a experiência da Comuna de Paris. Para ele,

\begin{abstract}
la revolución francesa fracasó porque la Communa se espantó del poder que tenía en su mano, y no fue hasta donde debía ir; a nosotros puede pasarnos lo mismo. Ahora que es tiempo de que tomemos medidas radicales para corregir nuestros males, ahora que es tiempo de que dictemos bases sólidas, bases sabias y para asegurar ese futuro, para asegurar un porvenir risueño para la patria, no debemos detenernos ante los escrúpulos, sino seguir adelante. (Idem, p.224)
\end{abstract}

Ou seja, escrúpulos levantados sobre como o texto, por exemplo, poderia gerar tensões com os interesses estrangeiros - e de fato gerou muitas durante as duas décadas seguintes - não poderiam limitar a obra constitucional, devendo essa ser eminentemente radical.

\footnotetext{
${ }^{35}$ Essa não chega a ser uma categoria que Koselleck se preocupa em precisar bem seu significado, mas seu sentido fica sugerido na leitura de um de seus trabalhos (KOSELLECK, 2006, p.61-77), no qual menciona a Declaração dos Direitos do Homem e do Cidadão como constitutiva de um "campo de expectativa social". Para ele, após a Declaração, "todos os programas lançados em nome da liberdade e/ou igualdade pressionavam por uma realização subsequente" (Idem, p.71).
}

Revista Eletrônica da ANPHLAC, n.12, p. 196-228, jan./jun. 2012. http://revista.anphlac.org.br/index.php/revista 
Diferentemente da "concórdia geral" conseguida entre os constituintes com a aprovação unânime do artigo 27 , trago o caso do artigo $3^{\circ}$, que reproduzo abaixo tal e qual se aprovou em 1917. Ele dizia:

La enseñanza es libre; pero será laica la que se dé en los establecimientos oficiales de educación, lo mismo que la enseñanza primaria, elemental y superior que se imparta en los establecimientos particulares.

Ninguna corporación religiosa, ni ministro de algún culto podrán establecer o dirigir escuelas de instrucción primaria.

Las escuelas primarias particulares sólo podrán establecerse sujetándose a la vigilancia oficial.

En los establecimientos oficiales se impartirá gratuitamente la enseñanza primaria. (MÉXICO, 2010, p.878)

A votação produziu uma considerável divisão no Congresso, e os debates registraram bem as diferenças entre as duas principais tendências da constituinte. Para melhor ilustrar essa situação, me detenho no confronto entre duas intervenções. De um lado está a fala do gal. Francisco Múgica, presidente da Comissão de Constituição e, reconhecidamente, o mais ativo jacobino ${ }^{36}$. Para ilustrar o ideal do grupo renovador, escolhi a intervenção do deputado Luís Manuel Rojas, presidente do Congresso Constituinte.

O grande ponto de discórdia ficou por conta do exacerbado anticlericalismo embutido no texto apresentado, característica que se manifestava constantemente entre os jacobinos. O projeto inicial de Carranza não fugiu muito do que já estava posto no Código de 1857, com a única mudança significativa de determinar a laicidade do ensino nos estabelecimentos "oficiais" (leia-se "públicos"). Tal proposta não foi suficiente para os jacobinos, que ambicionavam estender o princípio da laicidade também para estabelecimentos privados de ensino. Em sua defesa, Múgica disse que o momento de discutir o artigo sobre a educação era o mais solene da revolução; isso porque

\begin{abstract}
en aquellas etapas gloriosas [da Guerra Civil] no se trataba más que de vencer de una vez por todas al que tenía el Poder usurpado en sus manos o de acabar con la reacción, y aquí, señores, se trata nada menos que del porvenir de la patria, del porvenir de nuestra juventud, del porvenir de nuestra niñez, del porvenir de nuestra alma máter, que debe engendrarse en los principios netamente nacionales y en principios netamente progresistas [...]. (MÚGICA, 1967, p.75)
\end{abstract}

\footnotetext{
${ }^{36}$ Juan de Dios Bojórquez, sendo ele mesmo um componente dos jacobinos, diz que eles "no tuvieron líder; pero si recordamos a quienes mejor expusieron su manera de pensar, de seguro que llegaremos a esta conclusión: el batallador general Múgica, fue el abanderado de las izquierdas de Querétaro" (apud ROUAIX, 1959, p.232). Pastor Rouaix, por sua vez, concederia ao primeiro presidente da Comissão de Constituição (a qual também integrou) a qualidade de deputado mais ativo e eficaz da Constituinte (ROUAIX, 1959, p.238).
} 
Para ele, justamente pela importância da educação em engendrar "as ideias fundamentais no homem" é que se deveria combater com toda a força qualquer direito do clero tomar parte nesses assuntos. $\mathrm{Na}$ série de argumentos que elenca para desqualificar as corporações religiosas e seus integrantes - chegando a ponto de considerar o clero como anticristão (Idem, p.75-76) -, detenho-me no último, pois me pareceu mais digno de nota. Múgica remonta às lutas internas do século XIX entre o Partido Liberal e o Partido Conservador, nas quais a Igreja Católica se alinhava tradicionalmente com os conservadores; e daí surge a sua máxima de que o clero "es el eterno rebelde", constantemente "preparando el terreno para más tarde dar el golpe" (Idem, p.76). Vale lembrar que dita "rebeldia clerical" não estava tão distante historicamente, uma vez que a Igreja Católica apoiou ostensivamente o governo golpista de Victoriano Huerta (WOMACK, 2002, p.129). Dessa forma, para o deputado jacobino, a própria possibilidade da paz duradoura residia em impedir que o clero tomasse parte no ensino (MÚGICA, 1967, p.76-77). Seu discurso terminava com as seguintes palavras:

si dejamos la libertad de enseñanza absoluta para que tome participación en ella el clero con sus ideas rancias y retrospectivas, no formaremos generaciones nuevas de hombres intelectuales y sensatos, sino que nuestros pósteros recibirán de nosotros la herencia del fanatismo, de principios insanos, y surgirán más tarde otras contiendas que ensangrentarán de nuevo a la patria, que le arruinarán y que quizá la llevarán a la pérdida total de su nacionalidad. (Idem, p.77)

Ou seja, a "liberdade", tema bastante sensível para os renovadores, não podia ser tão "absoluta", a ponto de tolerar que o clero (compreendido pelos jacobinos como uma força da "reação") tomasse parte na instrução dos futuros homens do país, de forma que a durabilidade da paz recaía sobre essa decisão.

Por sua vez, o renovador Luís Manuel Rojas expressou uma maneira diferente de encarar a questão. Para ele,

Podrá suceder que de aquí salga un Código netamente liberal, tolerante, progresista y moderno; un Código Magno que sirva para restablecer cuanto antes la paz en México y para garantizar su estabilidad por un tiempo indefinido, que ojalá y fuese definitivamente. Podrá ser también que esta Constitución, por circunstancias especiales, revista un aspecto alarmante para las personas que no entienden que el apasionamiento do los señores diputados en esta ocasión, queriendo por ello calificar nuestra obra común como imprudente e inoportunamente jacobina, $y$, por consiguiente, reaccionaria. [grifos meus] (ROJAS, 1967, p.77-78)

Revista Eletrônica da ANPHLAC, n.12, p. 196-228, jan./jun. 2012. http://revista.anphlac.org.br/index.php/revista 
Em oposição a Múgica, Rojas acreditava que a questão da paz deveria ser estabelecida por um texto constitucional tolerante, de forma que um "jacobinismo extemporáneo y inoportuno [...] nos pueda llevar también a una nueva contienda armada" (Idem, p.87), e, no fundo, seria uma postura reacionária diante dos princípios liberais oitocentistas. Ainda que estimasse a liberdade gozada nos países anglo-saxões, o deputado renovador reconhece que, em países de maioria católica, pela submissão aos preceitos emanados de Roma, sejam justificadas restrições políticas mais violentas a respeito do clero; justificadas também seriam tais atitudes no calor da luta armada (Idem, p.87). Entretanto, o Congresso Constituinte deveria ser o momento da "razão dos espíritos serenos" (Idem, p.88) e não seria prudente que fosse dominado pelo impulso que os levaram da guerra até aquela ocasião.

Da mesma maneira, o “jacobinismo" só seria “desculpável”, na medida em que a Igreja Católica conservasse o predomínio sobre o espírito público (Idem, p.80), o que, no seu entendimento, não ocorria. Para Rojas, as Leyes de Reforma do século XIX que expropriaram os bens eclesiásticos e estabeleceram a separação formal entre Igreja e Estado - já haveria debelado o dito domínio clerical; daí classificar como “extemporânea" a "fórmula intolerante y agresiva que nos propone la Comisión para el artículo $3^{\circ}$ " (Ibidem).

No final de seu discurso, o deputado renovador tentou uma moção, para que fosse retirado o ditame apresentado pela Comissão de Constituição a fim de reescrevêlo, no sentido de tornar o texto do artigo menos "escandaloso" e mais respeitoso da figura do Primeiro Chefe Carranza que, excepcionalmente, presenciava as discussões sobre esse artigo (ROJAS, 1967, p.93). Rojas teve sua moção negada e, com o resultado de 98 votos a favor e 58 contrários, foi aprovado o artigo $3^{\circ}$ da Constituição de 1917 na forma em que foi defendida por Francisco Múgica (a exceção do impedimento geral aos ministros de culto de proferir ensino pessoalmente em qualquer colégio).

\section{Considerações finais}

Pastor Rouaix, em seu estilo conciliador de extremos, disse que, não obstante o choque entre jacobinos e renovadores, não houve no Congresso Constituinte de Querétaro "reaccionarios ni conservadores, porque todos los diputados ambicionaban ir 
de frente, siempre adelante, arrollando obstáculos y sólo diferían en la velocidad con que debería recorrerse el camino" (ROUAIX, 1959, p.63). Certamente, esse julgamento é questionável, a depender dos critérios que se utilize. Contudo, parece razoável defender que nenhum dos deputados estava disposto a ignorar completamente as demandas transformadoras populares da revolução; creio ter sido exemplo disso a aprovação unânime do artigo 27. Nas discussões sobre esse artigo, lembrou o deputado Luís T. Navarro, que as exigências por terra continuavam vivas e ainda se faziam atuantes de forma armada com os zapatistas, por exemplo. Por mais que esses, naquele momento, estivessem restringidos ao estado de Morelos, seriam sempre um desafio para a paz nacional enquanto não se fizesse as concessões agrárias que exigia a população (NAVARRO, 1967, p.229).

Dentre as duas tendências principais, os renovadores eram os mais moderados, apegados (talvez demasiadamente) à "razão dos espíritos serenos", emanada da herança do liberalismo oitocentista. Porém, como disse Heriberto Jara no discurso aludido acima, era decisivo que os constituintes não se deixassem limitar pelo que foi conquistado no passado, pois "lo que era considerado antes como radical, se pueda considerar ahora como retardatario, porque no es suficiente para cubrir, para remediar las necesidades actuales" (JARA, 1967, p.222). Nesse sentido, ainda que se reconheça o valor do grupo renovador nos trabalhos do Congresso, ainda que se opte pela tese de que a maioria dos deputados não fazia parte das duas tendências principais (ROUAIX, 1959, p.64), creio ser possível afirmar que o tom revolucionário da Constituição de 1917, aquilo que lhe levou além do espaço pré-definido da Carta Magna anterior, esse tom foi impulsionado pelos jacobinos. Essa ala, demostrando clara insatisfação com as limitações da fórmula dos políticos liberais tradicionais, foi a maior responsável por transformar o documento legal-normativo da nação em testamento da "catártica guerra civil" (AGUILAR CAMÍN, 1994, p.11), agregando-lhe um "campo de expectativa social” próprio à Revolução Mexicana. Enquanto tal, a nova Constituição iria pairar como elemento de pressão constante para os governos seguintes, sempre instando aqueles que pretendem ocupar os altos cargos políticos, pela realização de seus amplos ideais revolucionários.

Em uma visão panorâmica sobre o México da primeira metade do século XX, chamou-me a atenção, a discrepância entre: por um lado, os avançados postulados da 
Constituição de 1917 (e seu indissociável desdobramento radical dos anos 1930); por outro, o que me pareceu uma excessiva prudência legalista de líderes como Francisco Madero e Venustiano Carranza; além disso, os caudilhos de extração popular mais lembrados - Villa e Zapata - foram derrotados militarmente e eram os principais inimigos no momento do Congresso Constituinte, o que leva à questão de como a orientação política mais estritamente liberal (da qual Madero e Carranza eram caudatários) foi colocada em segundo plano na construção da nova ordem política mexicana?

Foi ao me familiarizar com a repartição de terras de Lucio Blanco, as ações dos jovens oficiais nortistas e, principalmente, com as intervenções dos deputados jacobinos em Querétaro que, então, pude entrever como foi possível ao impulso da guerra civil (dentro do grupo vencedor) proporcionar, no fim, que a norma constitucional de 1917 se desembaraçasse do projeto inicial de reformar antiga Carta de 1857 e se convertesse, então, na tarefa de criar outra verdadeiramente nova.

\section{Referências documentais}

CARRANZA, Venustiano. Adiciones al Plan de Guadalupe. Veracruz, 12 dez. 1914. In: SILVA HERZOG, Jesús. Breve historia de la Revolución Mexicana. La etapa constitucionalista y la lucha de facciones. México: Fondo de Cultura Económica, 1972a. p. 194-203.

. Decreto de 6 de enero de 1915, declarando nulas todas las enajenaciones de tierras, aguas y montes pertenecientes a los pueblos, otorgadas en contravención a lo dispuesto en la ley del 25 de junio de 1856. In: GARCIADIEGO, Javier (Org.). Textos de la Revolución Mexicana. Caracas: Biblioteca Ayacucho, 2010. p.430-436. Disponível em:

$<$ http://www.bibliotecayacucho.gob.ve/fba/index.php?id=97\&backPID=103\&begin_at= 176\&tt products=362>. Acesso em 24 jan. 2012.

. Decreto para la formación de un Congreso Constituyente, 14 set.

1916. In: ROUAIX, Pastor. Génesis de los artículos 27 y 123 de la Constitución Politica de 1917. México: Instituto Nacional de Estudios Históricos de la Revolución Mexicana (INEHRM), 1959. Disponível em:

Revista Eletrônica da ANPHLAC, n.12, p. 196-228, jan./jun. 2012. http://revista.anphlac.org.br/index.php/revista 
$<$ http://www.bicentenario.gob.mx/bdbic/index.php?option=com_booklibrary\&task=vie

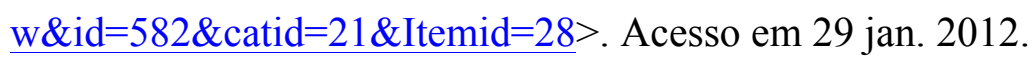

. Un discurso trascendental del señor Carranza, en el ayuntamiento de Hermosillo, Sonora, 24 set. 1913. In: SILVA HERZOG, Jesús. Breve historia de la Revolución Mexicana. La etapa constitucionalista y la lucha de facciones. México: Fondo de Cultura Económica, 1972b. p.59-64.

DÍAZ, Porfírio. El presidente Díaz. Héroe de las Américas. Pearson's Magazine, mar. 1908. Entrevista concedida a James Creelman. In: GARCIADIEGO, Javier (Org.). Textos de la Revolución Mexicana. Caracas: Biblioteca Ayacucho, 2010. p.92-137. Disponível em: $<$ http://www.bibliotecayacucho.gob.ve/fba/index.php?id=97\&backPID=103\&begin_at= 176\&tt_products=362>. Acesso em: 24 jan. 2012.

GUTIÉRREZ, Eulálio. Decreto sobre el salario mínimo. In: SILVA HERZOG, Jesús. Breve historia de la Revolución Mexicana. La etapa constitucionalista y la lucha de facciones. México: Fondo de Cultura Económica, 1972. p.190-193.

HUERTA, Victoriano. Decretos de Victoriano Huerta con motivo de la disolución de las cámaras, 10-12 out. 1913. In: SILVA HERZOG, Jesús. Breve historia de la Revolución Mexicana. La etapa constitucionalista y la lucha de facciones. México: Fondo de Cultura Económica, 1972. p.104-113.

JARA, Heriberto. Las reivindicaciones sociales y nacionales en el artículo 27. In: INSTITUTO NACIONAL DE ESTUDIOS HISTÓRICOS DE LA REVOLUCIÓN MEXICANA (INEHRM). 50 discursos doctrinales en el Congreso Constituyente de la Revolución mexicana 1916 - 1917. México: Instituto Nacional de Estudios Históricos de la Revolución Mexicana, 1967. p.219-225. Disponível em: $<$ http://www.bicentenario.gob.mx/bdbic/index.php?option=com_booklibrary\&task=vie w\&id=579\&catid=21\&Itemid=28> . Acesso em: 29 jan. 2012.

MADERO, Francisco I. Plan de San Luis Potosí, San Luis Potosí, 5 out. 1910. In: CÓRDOVA, Arnaldo. La ideología de la Revolución mexicana. México: Ediciones Era, 1979. p.428-434.

MÉXICO (país). Constitución Política de los Estados Unidos Mexicanos. Querétaro, 5 febrero 1917. In: LEMOINE, Ernesto; MUÑOZ, Horacio Labastida; BATRES, Oscar Castañeda. Documentos para la historia del México independiente, 1808-1938: 
insurgencia y república federal, reforma y república restaurada, Revolución Mexicana y Constitución de 1917. México: Miguel Ángel Porrúa, 2010. p.877-946. Disponível em: $<$ http://www.diputados.gob.mx/cedia/biblio/virtual/bicentena/doc_hist_inde/05_C_secc _doc.pdf>. Acesso em: 25 jan. 2012.

MÚGICA, Francisco J. El artículo $3^{\circ}$. In: INSTITUTO NACIONAL DE ESTUDIOS HISTÓRICOS DE LA REVOLUCIÓN MEXICANA (INEHRM). 50 discursos doctrinales en el Congreso Constituyente de la Revolución mexicana 1916 - 1917. México: Instituto Nacional de Estudios Históricos de la Revolución Mexicana, 1967. p.74-77. Disponível em:

$<$ http://www.bicentenario.gob.mx/bdbic/index.php?option $=$ com_booklibrary\&task=vie

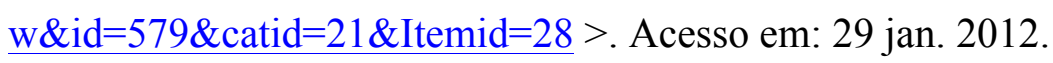

NAVARRO, Luis T. Las reivindicaciones sociales y nacionales en el artículo 27. In: INSTITUTO NACIONAL DE ESTUDIOS HISTÓRICOS DE LA REVOLUCIÓN MEXICANA (INEHRM). 50 discursos doctrinales en el Congreso Constituyente de la Revolución mexicana 1916 - 1917. México: Instituto Nacional de Estudios Históricos de la Revolución Mexicana, 1967. p.226-232. Disponível em: $<$ http://www.bicentenario.gob.mx/bdbic/index.php?option $=$ com_booklibrary\&task=vie w\&id=579\&catid=21\&Itemid=28>. Acesso em: 29 jan. 2012.

OBREGÓN, Álvaro. Decreto del General Obregón sobre salario mínimo, 09 abr. 1915. In: SILVA HERZOG, Jesús. Breve historia de la Revolución Mexicana. La etapa constitucionalista y la lucha de facciones. México: Fondo de Cultura Económica, 1972. p. 259-261.

PLAN DE AYALA. Ayala, Morelos, 28 nov. 1911. In: CÓRDOVA, Arnaldo. La ideología de la Revolución mexicana. México: Ediciones Era, 1979. p.435-439.

PLAN DE GUADALUPE. Hacienda de Guadalupe, Coahuila, 26 de mar. de 1913. In: CÓRDOVA, Arnaldo. La ideología de la Revolución mexicana. México: Ediciones Era, 1979. p.444-446.

RATIFICACIÓN del Plan de Ayala. San Pablo Oxtotepec, 19 jun. 1914. In: CÓRDOVA, Arnaldo. La ideología de la Revolución mexicana. México: Ediciones Era, 1979. p.441-443.

REFORMAS al Plan de Ayala, Morelos, 30 mai. 1913. In: CÓRDOVA, Arnaldo. La ideología de la Revolución mexicana. México: Ediciones Era, 1979. p.440.

Revista Eletrônica da ANPHLAC, n.12, p. 196-228, jan./jun. 2012. http://revista.anphlac.org.br/index.php/revista 
ROJAS, Luis Manuel. El artículo $3^{\circ}$. In: INSTITUTO NACIONAL DE ESTUDIOS HISTÓRICOS DE LA REVOLUCIÓN MEXICANA (INEHRM). 50 discursos doctrinales en el Congreso Constituyente de la Revolución mexicana 1916 - 1917. México: Instituto Nacional de Estudios Históricos de la Revolución Mexicana, 1967. p.77-96. Disponível em:

$<$ http://www.bicentenario.gob.mx/bdbic/index.php?option=com_booklibrary\&task=vie $\underline{\text { w } \& \mathrm{id}=579 \& \text { catid=21\&Itemid=28> }}$. Acesso em: 29 jan. 2012.

SOBERANA CONVENCIÓN REVOLUCIONARIA (México, país). Ley Agraria, 26 out. 1915. In: CÓRDOVA, Arnaldo. La ideología de la Revolución mexicana. México: Ediciones Era, 1979. p.471-477.

TRATADOS DE CIUDAD JUÁREZ, 21 mai. 1911. In: GARCIADIEGO, Javier (Org.). Textos de la Revolución Mexicana. Caracas: Biblioteca Ayacucho, 2010. p.221222. Disponível em:

$<$ http://www.bibliotecayacucho.gob.ve/fba/index.php?id=97\&backPID=103\&begin_at= 176\&tt products=362>. Acesso em: 24 jan. 2012.

TRATADOS DE TEOLOYUCAN, 13 ago. 1914. In: GARCIADIEGO, Javier (Org.). Textos de la Revolución Mexicana. Caracas: Biblioteca Ayacucho, 2010. p.372-374. Disponível em: $<$ http://www.bibliotecayacucho.gob.ve/fba/index.php?id=97\&backPID=103\&begin_at= 176\&tt_products=362>. Acesso em: 24 jan. 2012.

\section{Referências bibliográficas}

AGUILAR CAMÍN, Héctor. Ovación, denostación y prólogo. In: GILLY, Adolfo et al. Interpretaciones de la Revolución Mexicana. México: Editorial Nueva Imagen, 1994. p.11-19 ; MEYER, Lorenzo. À sombra da Revolução Mexicana. História Mexicana Contemporânea, 1910-1989. São Paulo: Editora da Universidade de São Paulo, 2000.

BARBOSA, Carlos Alberto Sampaio. 20 de novembro de 1910: a Revolução Mexicana. São Paulo: Lazuli, 2008. 
. A fotografia a serviço de Clio: uma interpretação da história visual da Revolução Mexicana (1900-1940). São Paulo: Editora UNESP, 2006.

BARRAGÁN RODRÍGUEZ, Juan. Historia del ejército y de la revolución constitucionalista. Primera época. México: Instituto Nacional de Estudios Históricos de la Revolución Mexicana (INEHRM), 1985. Disponível em: $<$ http://www.bicentenario.gob.mx/bdbic/index.php?option $=$ com_booklibrary\&task=vie w\&id=471\&catid=32\&Itemid=99999999>. Acesso em: 20 jan. 2012.

- Historia del ejército y de la revolución constitucionalista. Tercera época. México: Instituto Nacional de Estudios Históricos de la Revolución Mexicana (INEHRM), 1986. Disponível em: $<$ http://www.bicentenario.gob.mx/bdbic/index.php?option $=$ com_booklibrary\&task=vie $\underline{w} \& \mathrm{id}=473 \&$ catid=32\&Itemid=99999999 $>$. Acesso em: 23 jan. 2012.

BOJÓRQUEZ, Juan de Dios. Forjadores de la Revolución Mexicana. México: Instituto Nacional de Estudios Históricos de la Revolución Mexicana (INEHRM), 1960. Disponível em: $<$ http://www.bicentenario.gob.mx/bdbic/index.php?option $=$ com_booklibrary\&task=vie w\&id=663\&catid=21\&Itemid=28> . Acesso em: 20 jan. 2012.

BROWN, Lyle C. Mexico's Constitution of 1917. In: WILKIE, James W.; MICHAELS, Albert (Eds.). Revolution in Mexico: years of upheaval, 1910-1940. Nova York: Alfred A. Knopf, 1969. p.60-72.

CÓRDOVA, Arnaldo. La formación del poder político en México. México: Ediciones Era, 2003.

MIRANDA CORREA, Eduardo. El artículo 27 en el Congreso Constituyente de Querétaro. Un análisis social. México: Instituto de Investigaciones Jurídicas, s/d. Disponível em: <http://biblio.juridicas.unam.mx/libros/2/722/13.pdf> . Acesso em: 24 jan. 2012.

DÍAZ, Lilia. El liberalismo militante. In: COSÍO VILLEGAS, Daniel (coord.). Historia general de México. México: El Colegio de México, 1981. Tomo 2. p.819-896.

GILLY, Adolfo. El cardenismo: una utopía mexicana. México: Ediciones Era, 2001.

Revista Eletrônica da ANPHLAC, n.12, p. 196-228, jan./jun. 2012. http://revista.anphlac.org.br/index.php/revista 
GONZÁLEZ, Luis. El liberalismo triunfante. In: COSÍO VILLEGAS, Daniel (Coord.). Historia general de México. México: El Colegio de México, 1981. Tomo 2. p. 8971015.

KATZ, Friedrich. O México: a república restaurada e o Porfiriato, 1867-1910. In: BETHELL, Leslie (Org.). História da América Latina: volume 5, de 1870 a 1930. São Paulo: Edusp, 2002. p.23-103.

KNIGHT, Alan. El gen vivo de un cuerpo muerto. In: Nexos, 01 nov. 2009. Disponível em: <http://www.nexos.com.mx/?P=leerarticulo\&Article=29020>. Acesso em: 16 out. 2011.

KOSELLECK, Reinhart. Futuro passado: contribuição à semântica dos tempos históricos. Rio de Janeiro: Contraponto;Ed. PUC-Rio, 2006.

PAZ, Octavio. O labirinto da solidão e post scriptum. Rio de Janeiro: Paz e Terra, 2006.

QUIRK, Robert E. Battle of Celaya. In: WILKIE, James W.; MICHAELS, Albert (Eds.). Revolution in Mexico: years of upheaval, 1910-1940. Nova York: Alfred A. Knopf, 1969a. p.107-111

. Villa meets Zapata. In: WILKIE, James W.; MICHAELS, Albert (Eds.). Revolution in Mexico: Years of upheaval, 1910-1940. Nova York: Alfred A. Knopf, 1969b. p.78-83.

ROMERO, José Luís. América Latina: as cidades e as ideias. Rio de Janeiro: Editora UFRJ, 2004.

ROUAIX, Pastor. Génesis de los artículos 27 y 123 de la Constitución Política de 1917. México: Instituto Nacional de Estudios Históricos de la Revolución Mexicana (INEHRM), 1959. Disponível em:

$<$ http://www.bicentenario.gob.mx/bdbic/index.php?option=com_booklibrary\&task=vie

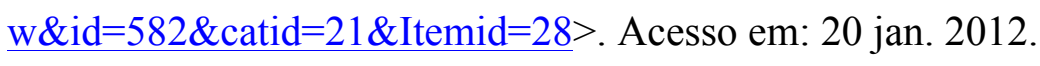

SILVA HERZOG, Jesús. Breve historia de la Revolución Mexicana. La etapa constitucionalista y la lucha de facciones. México: Fondo de Cultura Económica, 1972a. . Breve historia de la Revolución Mexicana. Los antecedentes y la etapa maderista. México: Fondo de Cultura Económica, 1972b.

Revista Eletrônica da ANPHLAC, n.12, p. 196-228, jan./jun. 2012. http://revista.anphlac.org.br/index.php/revista 
ULLOA, Berta. La lucha armada (1911-1920). In: COSÍO VILLEGAS, Daniel (Coord.). Historia general de México. México: El Colegio de México, 1981. Tomo 2. p.1073-1182.

WILKIE, James W.; MICHAELS, Albert (Eds.). Revolution in Mexico: years of upheaval, 1910-1940. Nova York: Alfred A. Knopf, 1969.

WOMACK, John Jr. A Revolução Mexicana, 1910-1920. In: BETHELL, Leslie (Org.). História da América Latina: volume 5, de 1870 a 1930. São Paulo: Edusp, 2002. p.105191.

Revista Eletrônica da ANPHLAC, n.12, p. 196-228, jan./jun. 2012. http://revista.anphlac.org.br/index.php/revista 